\title{
Technological Effectiveness of Chelated Micronutrient Fertilizers in Leaf Treatments Inducing Grapes Resistance to Biotic and Abiotic Stresses
}

\author{
Eugeniya Yurchenko $^{1, *}$, and Alexander Artamonov ${ }^{2}$ \\ 1 Federal State Scientific Budget Institution «North-Caucasian Federal Scientific Center of \\ Horticulture, Viticulture, Winemaking», 39, 40-letia Pobedy, Krasnodar, 350901, Russia \\ 2 Agrofirma "Yuzhnaya", JSC (joint-stock company) 158, Karl Marx st., Taman, Temryuk district, \\ Krasnodar region, 353555, Russia
}

\begin{abstract}
Fertilizers based on complexes of chelated trace elements are the most common and effective agricultural products for the induction of protective-compensatory and other adaptive reactions of plants. The influence of various leaf treatments technologies with chelated micronutrient fertilizers application on the stability of grapes is studied under increasing abiotic and biotic environment factors within the Taman Peninsula (Russia) considering the content of proline, photosynthetic pigments (chlorophylls and carotenoids), total water in the leaves, as well as the development of infectious drying of clusters and leaf spotting reduction due to the treatment. The new optimized scheme application on the chelated micronutrient fertilizers showed a predominantly positive effect on the grape plants adaptation to high-temperature drought and fungal diseases susceptibility, as well as essential increase of the average cluster weight and yield per hectare.
\end{abstract}

\section{Introduction}

Industrial vineyards located on the Taman Peninsula in the main agroecological zone of viticulture in the Krasnodar Territory (Russia) are mainly large arrays of perennial plantings, on the territory from 20 to 100 or more hectares and appear to be largely anthropogenically loaded agroecosystems. In regional technologies for growing grapes, 1014 pesticidal treatments are used, several agrotechnical operations with a bush are carried out to control the yield of berries and foliage, including the mechanized ones, with1-2-time herbicides application and 3-5 soil cultivations a season.

The global climatic changes observed recently $[1,2]$ are reflected everywhere, including the weather and climate conditions of the Taman Peninsula, where recent changes in the hydrological and temperature conditions, a regime of circulation of air masses in the atmosphere are recorded, alongside with different kinds of weather anomalies - wind

"Corresponding author: yug.agroekos@yandex.ru 
loads, and heat/cold irregular tides. Against the background of a high anthropogenic load, an increase of the abiotic factor becomes critical, and the risks of phytosanitary and production instability of ampelocenoses arise. As many researchers note, any weather stress weakens grape plants, reducing its resistance to pests and diseases [3, 4]. New harmful diseases appear, the causative agents of which are micromycetes - hemibiotrophs with the pronounced thermophilicity and low air humidity tolerance $[5,6]$.

Optimization of the grape plants adaptive potential along with the low-toxic plant protection products application (based on natural or synthesized active substances, living producers) is the basic principle for creating modern adaptively integrated systems protecting grapes from harmful organisms. It is possible to reduce the impact of environmental stressors on plants not only via agroecological zoning of crops, but also, alongside with this, it is possible to optimize environmental conditions using various agrotechnical techniques, such as soil cultivation, fertilizers application, regulated irrigation, etc., including folia application / leaf treatments with biologically active substances [7].

The effectiveness of the leaf treatments with various macro- and microelements to increase the productivity, marketability and quality of fruits in various perennial crops is shown in many studies [8, 9, 10]. The list of active substances (of various genesis), with properties that activate the resistance of plants, is constantly updated, among them the microelements chelates should be specified. Fertilizers based on individual microelements in chelate form or their complexes are the most common and effective agricultural products for the induction of protective-compensatory reaction and other plants adaptive reactions widely used in various crops including grapes [11, 12, 13, 14].

Being mineral-organic complexes with a sophisticated structure including a special agent with the function of micronutrient ions capturing and remaining soluble until absorbed by plants, the microelement chelates have high bioavailability for crops, unlike salts of minerals - the chelate complex activates many processes during the plant growth [15]. The main objectives of chelated micronutrient fertilizers application in vineyards, along with improving the quality of the products obtained, are to activate the ability of plants to get them adapted to adverse environmental conditions and maintain their active life.

The aim of the research is to study the effectiveness of various technologies while the leaf treatments of grapes with fertilizer based on complexes of chelated microelements being applied to increase the adaptation of the culture to biotic and abiotic stresses.

\section{Materials and methods}

Field experiments were based on the vineyards of Agrofirma "Yuzhnaya", JSC (joint-stock company), (Temryuk district, Krasnodar Territory) located on the Taman Peninsula, $10 \mathrm{~km}$ from the coast of the Azov Sea during 2014-2015.

In 2014, the average air temperature on the Taman Peninsula in June was $1.5^{\circ} \mathrm{C}$ higher than the regular annual temperature. July, 2014, was hot, without precipitation. In August, 2014, dry conditions occurred, precipitation averaged about $10 \mathrm{~mm}$ per month $(20 \%$ of the norm), the first half of August was especially hot, as the maximum air temperature rose to + 37 and up to $+42{ }^{\circ} \mathrm{C}$. The air humidity dropped to $30 \%$. In 2015, on May 10-14, a steady transition of the average daily air temperature through $+15^{\circ}$ (the beginning of summer) was observed, which is 4-8 days later than the long-term annual average daily temperature. Early in June (June $05-07,2015$ ) a strong wind occurred at a speed of $15 \mathrm{~m} / \mathrm{s}$ or more for 24 days. During the first and second decades of June, 2015 the abundant dew precipitated due to the large difference in day and night temperatures. Since the 2nd decade of July, 2015 the hot weather had set in, the average decade-long air temperature was $2-3{ }^{\circ} \mathrm{C}$ higher 
than the norm, and the maximum air temperature rose to $33-38{ }^{\circ} \mathrm{C}$. There was a shortfall of precipitation by more than $15 \%$. In the 1 st and 2nd decades of August, 2015 a complex of agrometeorological phenomena occurred: hot, dry weather, a combination of atmospheric and soil drought. The atmosphere relative humidity for the decade was abnormally low.

For the experiments, the grapes varieties widespread in the region and genotypes were selected - Riesling Rhine (Vitis vinifera) and Bianca (Save Willard 12-375 x Chasselas Bouvier), as well as a complex interspecific hybrid $(V$. vinifera $+V$. labrusca $+V$. riparia + $V$ rupestris $+V$. berlandieri $+V$. aestivalis $+V$. cinerea $)$; everyone is early-medium ripening, white, technical.

\subsection{Experiment scheme}

The effectiveness of two different technologies for the application of foliar application with complex chelated micronutrient fertilizer Kelkat Mix Ca (Atlantica Agricola, Spain); chelated microfertilizer composition (\%): 3,0 (Ca EDTA); 2,3 (Fe EDTA); 1,9 (Fe DTPA); 2,6 (Mn EDTA); 0,55 (Zn EDTA); 0,55 (Cu EDTA); 0,55 (B); 0,15 (Mo) (Table 1, Fig. 1) was estimated.

Table 1. Scheme of experience

\begin{tabular}{|c|c|c|}
\hline \multirow{2}{*}{$\begin{array}{l}\text { Experience } \\
\text { options }\end{array}$} & \multicolumn{2}{|r|}{ Folia application technology description } \\
\hline & $\begin{array}{l}\text { Doses, } \\
1 / \text { ha }\end{array}$ & $\begin{array}{l}\text { Frequency and terms of application according to phenophases } \\
\qquad(\mathrm{BBCH})\end{array}$ \\
\hline $\begin{array}{l}\text { Foliar } \\
\text { application, } \\
\text { Technology } 1 \\
\text { (FA 1) }\end{array}$ & $\begin{array}{l}2.0 \\
2.0 \\
2.0\end{array}$ & $\begin{array}{l}57 \text { The flower buds fully developed, individual flowers separated } \\
73 \text { Grape-sized berries } \\
79 \text { The end of bunch formation }\end{array}$ \\
\hline $\begin{array}{l}\text { Foliar } \\
\text { application, } \\
\text { Technology } 2 \\
\text { (FA 2) }\end{array}$ & $\begin{array}{l}0.9 \\
1.0 \\
1.2 \\
1.3 \\
1.5\end{array}$ & $\begin{array}{l}57 \text { The flower buds fully developed, individual flowers separated; } \\
68 \text { The end of flowering, about } 80 \% \text { of perianths dropped, } \\
73 \text { Grape-sized berries: } \\
75 \text { Pea-sized berries, clusters sagging, } \\
79 \text { The end of bunch formation; }\end{array}$ \\
\hline Control & & No foliar application with microfertilizers \\
\hline
\end{tabular}

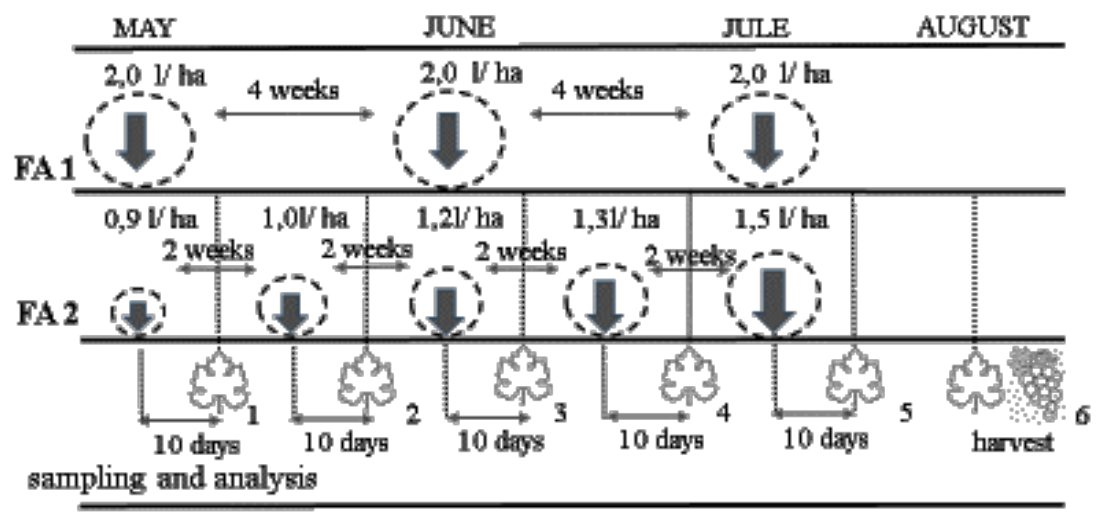

Fig. 1. Concept diagram of the experiment, FSSBI «North-Caucasian Federal Scientific Center of Horticulture, Viticulture, Winemaking», 2014-2015 
Each field experiment variant was located on a 2-hectare plot of vineyard. For each experimental plot (option), 40 model bushes (4 replicates of 10 bushes) were allocated, where regular phytosanitary monitoring of the main diseases was carried out during June, July and August 2014-2015 in terms of development (R, \%) and distribution (P, \%). From model bushes, some biological samples (leaves) were taken 6 times for laboratory analyses at the time indicated in the concept of the experiment (Fig. 1). Each sample contained 120 leaves per variant (30 leaves in each repetition). In the laboratory, 1 sample was divided into 3, 40 leaves per variant (10 leaves in each repetition), respectively, for each analysis (proline, pigments, hydration).

Technology 1 (FA 1) accepted on the farm, includes 3-fold sheet treatments with micronutrient fertilizers with equally high doses of $2.0 \mathrm{l} / \mathrm{ha}$, a total volume of $6.0 \mathrm{l} /$ ha and for long intervals. The regularity of the living biological systems response to irritating stimuli of various strengths was formulated as early as 1855 in the general biological law (Arndt-Schulz rule). Its significance for all living organisms is that, at low doses of the irritant, the body responds with stimulation, as the dose of exposure increases, the stimulating effect of the irritant is replaced by inhibition and then death of the body. The reaction of the body to any irritant, including leaf treatments with agricultural products, depends on the measure of its effect. Under conditions of increasing stressfulness of the vine growing environment, it was appropriate to assume that large doses of micronutrient fertilizers can be an additional stress for plants. Moreover, a large gap between treatments can adversely affect the vine, since immediately after the treatment the stimulation of metabolic processes begins, with large intervals between treatments, the effect fades. The repeated process of stimulation and extinction several times can ultimately lead to a weakening of the plant.

We proposed another Technology 2 (FA 2), which included 5-fold treatments (fractional), a time-distributed total volume of $5.9 \mathrm{l} / \mathrm{ha}$ and reduced single doses increasing as the foliage of the vine bushes grows. According to our assumption, such a technology should be more physiological for a plant with a higher efficiency in its resistance to stress factors.

\subsection{Research methodology}

The adaptive resistance of grape plants was studied under laboratory conditions by estimating the content of proline, photosynthetic pigments (chlorophylls and carotenoids), total water in the leaves; physiological and biochemical analyses were carried out at the Shared Research Educational Centre of FSSBI «NCFSCHVW» (Krasnodar, Russia) using spectrophotometry and capillary electrophoresis, as discussed by O. Hodek et al. (2017), N. P. Vlazan et al. (2012), N.I. Nenko et al. (2019), K. G. Tikhonov et al. (2017) [16, 17, 18, 19]. The biological effectiveness of leaf treatments with microfertilizers in controlling the development of major diseases was evaluated by reducing the intensity of disease development and was calculated using the Abbot formula, in this case an additional control option was left without fungicides and microfertilizers foliar application [20]. The grape productivity indicators (average bunch weight and yield per hectare) were considered and analysed during the harvesting period by weighing [20]. The diagrams of data dynamics for the content of biologically active substances were mathematically processed by the approximation method using the MS Office Excel software product. The water content and productivity indicators were processed using the dispersion method at the smallest significant difference at $5 \%$ level. 


\section{Results and discussion}

Photosynthetic activity often plays a key role in plant resistance to adverse external environmental factors; the important role of the photosynthetic pigments concentration for crop formation and the accumulation of plant bioenergy in agroecosystems is known. Photosynthesis of grape plants, being the basis of the production process, depends on many natural and anthropogenic environmental factors being geographically and climatically related $[21,22,23]$. Of particular importance is the photosynthesis relevance for plants that are constantly exposed to stress [24]. Along with chlorophylls, carotenoids play an important role in the process of photosynthesis, performing protective functions, in particular, they prevent the destructive photooxidation of organic compounds of protoplasm in the light, in presence of free oxygen. Under extensive insolation, an increased content of carotenoids was often found, which in this case carried out the function of protection against photoinhibition [25]. The products of the light-dependent phase of xanthophyll cycles are found to play an important role in protecting against oxidative stress caused not only by excess of light, but also by other factors generating reactive oxygen species (ROS), such as drought, heat [26].

The experimental results showed a steady positive effect of fractional systemic application of foliar application (FA 2) on the activation of photosynthesis. The effect was pronounced: a steady excess of the pigment content in the leaves was observed: compared to traditional technology (FA 1): on Riesling Rhine (sort), the sums of chlorophylls increased by $22.3-29.5 \%$ and the sums of carotenoids increased by $17.6-21.0 \%$ (Fig. 2, 3); in Bianca (sort), the sum of chlorophylls increased by 15.4-20.4 \% (Fig. 4).

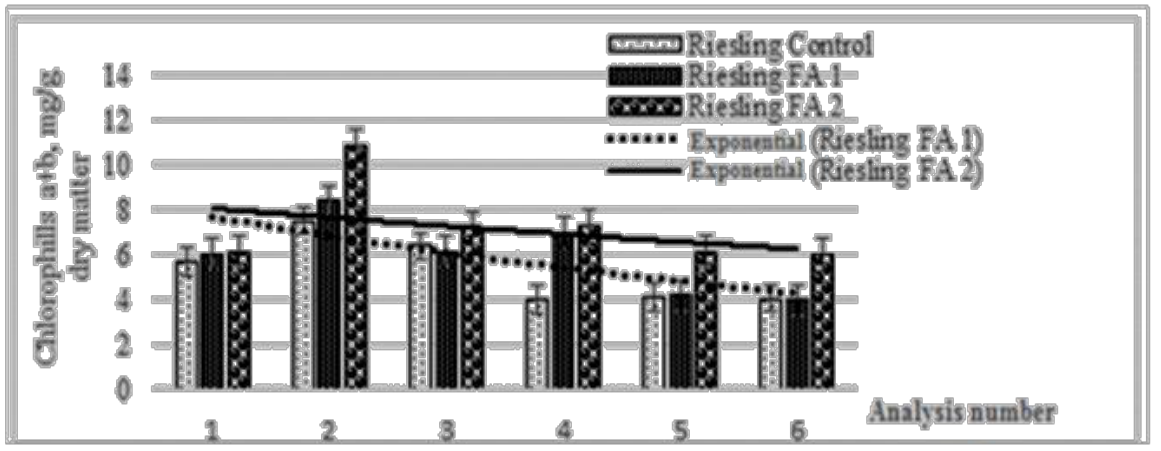

Fig. 2. Various technologies influence on the photosynthesis activity under the chelated micronutrient fertilizers application (the sums of chlorophylls, $\mathrm{a}+\mathrm{b}$, as $\mathrm{mg} / \mathrm{g}$ dry matter) for the grape leaves of Riesling Rhine, 2014

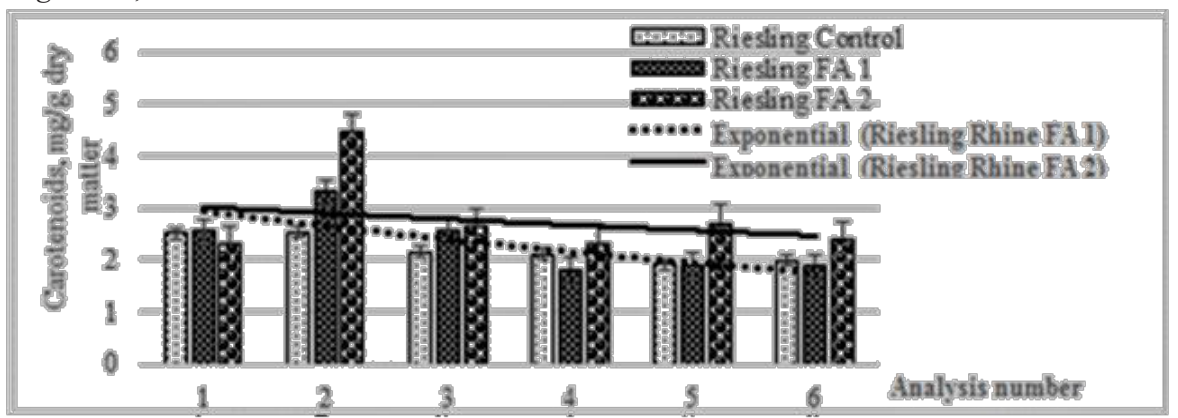

Fig. 3. Various technologies influence on the carotenoids content activity under the chelated micronutrient fertilizers application (mg/g dry matter) for the grape leaves of Riesling Rhine, 2014 


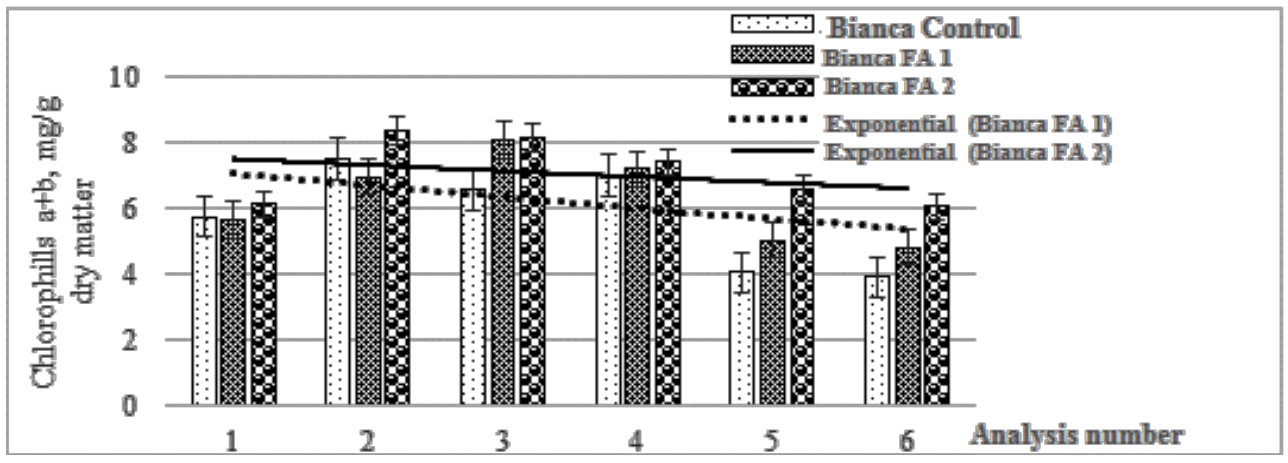

Fig. 4. Various technologies influence on the photosynthesis activity under the chelated micronutrient fertilizers application (the sums of chlorophylls, $\mathrm{a}+\mathrm{b}$, as $\mathrm{mg} / \mathrm{g}$ dry matter) for the grape leaves of Bianca, 2014

The same trend repeated in the second year of the experiment. The photosynthesis activation during 2 years of experimental work was more extended in FA 2 Technology, compared to FA 1 Technology, and it was especially conspicuously observed during the period of increased heat and aridity in July and August (2014-2015).

There is a positive correlation between the content of chlorophylls and the waterretaining ability in the leaves of woody plants, where a lack of water reduces the effectiveness of photosynthetic processes and quite significant changes can occur with a relatively high intensity of drought [27]. Under pressure of intense water deficiency, the grape plants productivity and quality are reduced due to the size of berries loss, the unfavourable ratio formation of skin and pulp, and inhibition of the biologically active compounds and dry substances in berries, positive accumulation of substances suffers from degradation in intensive draught [28, 29]. Under the high-temperature and lowered humidity conditions in summer period the interspecific hybrids (Euro-American vine) suffer a lot from alternaria spotting (Alternaria tenuissima (Kunze) Wiltshire) which is intensively developed in the region [6]. The analysis of leaves / folia treated according to various chelated micronutrient fertilizers technologies showed the best preservation of their water content in the variant of optimized processing technology (FA 2). The determined total water content was significantly higher on average by $2.2 \%$ in Riesling Rhine and $3.0 \%$ in Bianca. This tendency was observed during two years of experiments on both sorts during heat intensification in combination with low humidity at the end of July, 2014-2015 (Fig. 5), which characterizes a higher intensity of metabolic processes and adaptation of grape plants to drought.

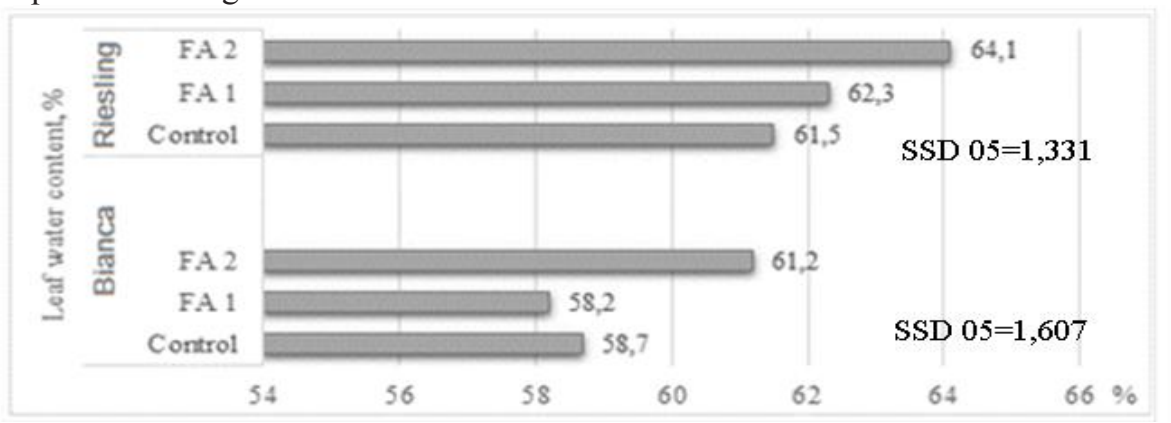

Fig. 5. Various technologies influence on the total water content under the chelated micronutrient fertilizers application on the grape leaves of Riesling Rhine and Bianca sorts, 2014-2015 
The protection against the damaging effect of ROS being one of the main destructive mechanisms in plants under stressful conditions is known to be effectively provided by a multi-stage protection system in which antioxidant enzymes play a leading role, but under the oxidative stress they can be inactivated by reactive oxygen and some time should pass before their synthesis gets restored. In this case, low-molecular antioxidant metabolites come to the fore [30], among which proline attracts the most attention, since it accumulates in plant cells under the influence of almost any stress factors. Stress-induced proline accumulation, having a multifunctional focus on the metabolism of cells, protects against DNA, proteins, lipids and a number of enzymes inactivation, it supports the oxidationreduction status of cells, and increases the overall adaptive potential of plants $[31,32]$. In the experiments, the proline content in dynamics was determined. An analysis of the data showed that with folia application technology (FA 2), the proline content was significantly higher compared to the control and technology option (FA 1), starting from the second decade of July 2014 and up to harvesting in 2015, for two years of experiments (Figs. 6, 7, 8, 9).

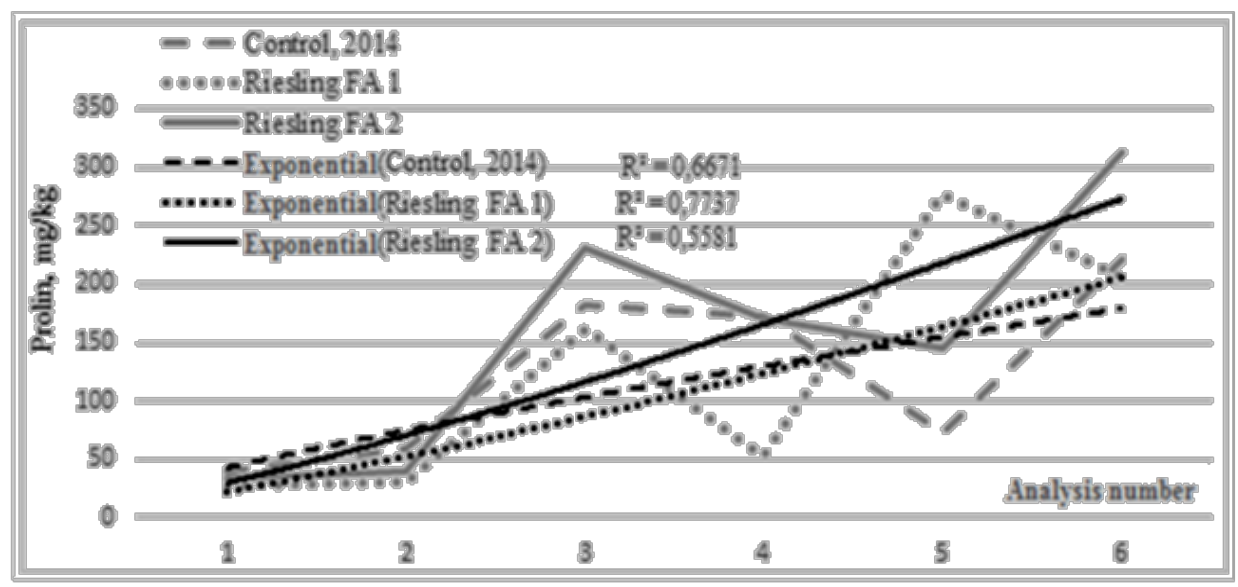

Fig. 6. Various technologies influence on the proline leaf accumulation dynamics under the chelated micronutrient fertilizers application on the grape leaves of Riesling Rhine, 2014

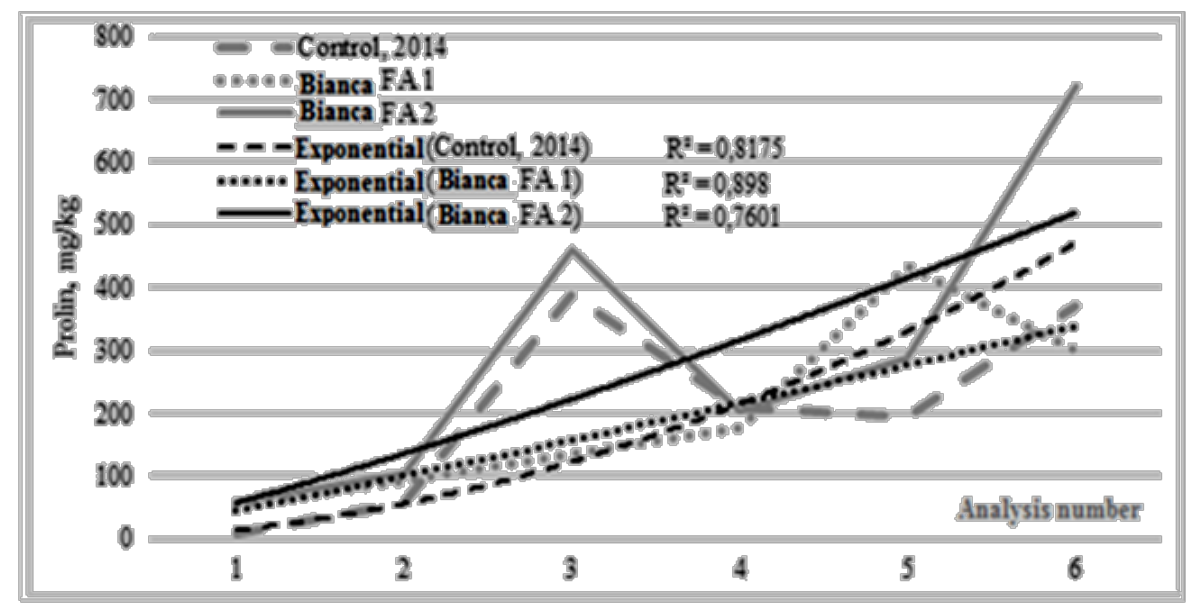

Fig. 7. Various technologies influence on the proline leaf accumulation dynamics under the chelated micronutrient fertilizers application on the grape leaves of Bianca, 2014 


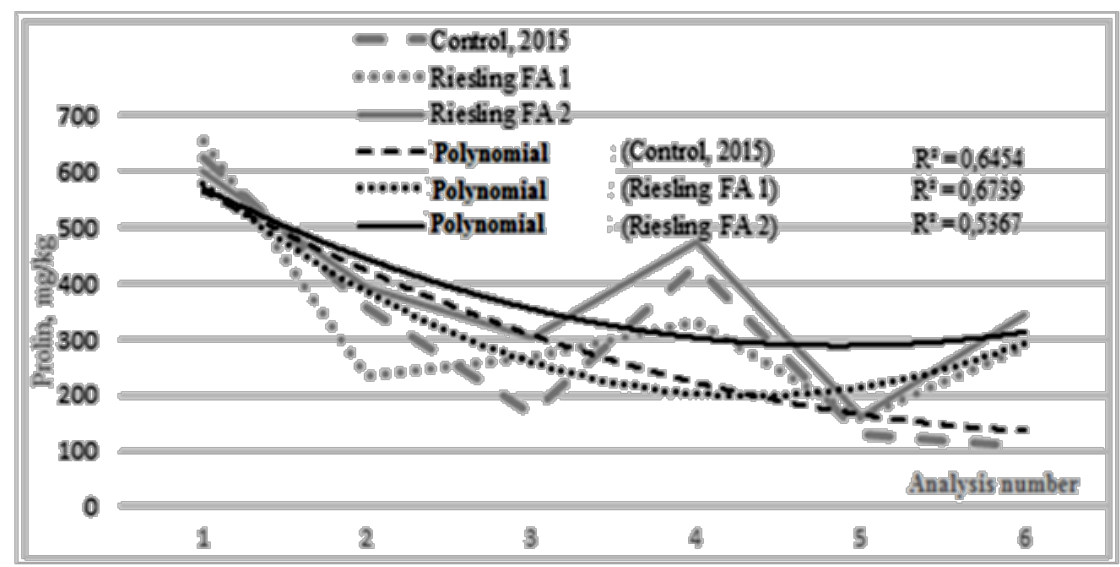

Fig. 8. Various technologies influence on the proline leaf accumulation dynamics under the chelated micronutrient fertilizers application on the grape leaves of Riesling Rhine, 2015

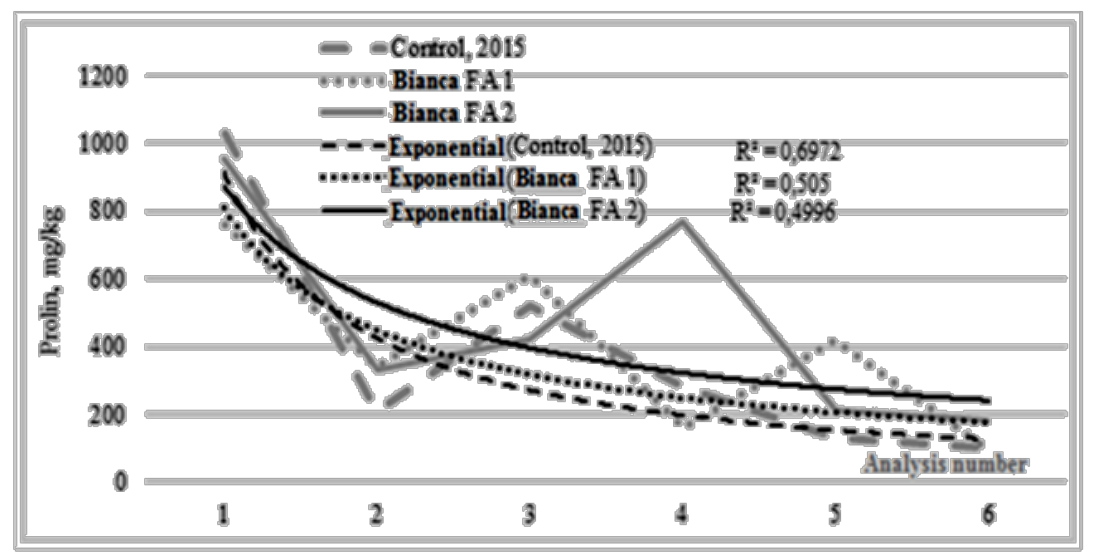

Fig. 9. Various technologies influence on the proline leaf accumulation dynamics under the chelated micronutrient fertilizers application on the grape leaves of Bianca, 2015

The given analysis examined the effectiveness of various technologies for leaf treatment with microelement chelates in increasing the resistance of grapes to biotic stressors, in particular to diseases. The development and spread of dominant grape diseases is evidently caused by obligate mycopathogens such as Erysiphe necator Schwein. anamororph; Oidium tuckeri Berk. teleomorph (oidium), Plasmopara viticola Berl. \& de Toni (mildew), effectively controlled by fungicides. The rot of berries, characteristic of Taman ampelocenoses, did not develop during the experiments due to weather conditions.

In summer season, under the extreme conditions of high air temperatures combined with aridity, it is more difficult to control diseases caused by hemibiotrophic species, since their biotic potential allows them to develop both on living and dead substrates, and especially on weakened plant tissues. The effective control of such diseases involves the use of special immuno-inducing agricultural practices.

In the European sort, Riesling Rhine, microelement leaf treatments efficiently coped with the harmful grape diseases in the Taman subzone, including drying of generative organs (Phomopsis viticola Sacc. + Fusarium proliferatum (Mats.) Nirenberg) and eutipellous leaf spot (Eutypella vitis (Schwein.) Ellis \& Everh) The drying of bunches was biological effectively controlled during the critical period in option (FA 2); it increased by 
12-16\% compared with the variant without leaf treatments (Control option). The difference between the options of various technologies was 3-5\% in favour of optimized technology (FA 2). It was also noted that the optimized use of chelated trace elements provides effective control of eutipellosis at the level of $96.5-100 \%$ without special protection measures. The difference between the control variant and the variant (FA 2) was significant and reached $20 \%$. In the Euro-American variety of Bianca, an increase in plant resistance to necrotic leaf spotting (A. tenuissima) was revealed with the use of leaf treatments with micronutrient fertilizers. The best results in their control were in the variants of optimized application (FA 2), the difference between the control variant and the optimised technology variant (FA 2) was from 3 to $17 \%$, between the variants FA 1 and FA 2 - from 3 to $8 \%$.

An integral indicator of the positive impact of agricultural practices is to increase the yield and quality of crop products. An analysis of the experimental results showed that the increase in the average bunch weight and the grapes yield per hectare with the optimized leaf treatments with chelated micronutrient fertilizers (FA 2) was significantly higher than the control variant, in contrast with the scheme (FA 1), where the increase in productivity was statistically insignificant (Tabl. 2).

Table 2. Various technologies influence on the productivity

of grapes with the chelated micronutrient fertilizers application, 2014-2015

\begin{tabular}{|l|c|c|c|c|}
\hline \multirow{2}{*}{ Variant } & \multicolumn{2}{|c|}{$\begin{array}{c}\text { Average bunch weight, } \\
\text { grams }\end{array}$} & $\begin{array}{c}\text { Productivity, t/ha } \\
\text { (combine harvesting) }\end{array}$ \\
\cline { 2 - 5 } & 2014 & 2015 & 2014 & 2015 \\
\hline \multicolumn{4}{|c|}{ Riesling Rhine } \\
\hline Control & 82,0 & 89,8 & 139,0 & 150,3 \\
\hline FA 1 & 83,9 & 94,5 & 138,0 & 153,2 \\
\hline FA 2 & 88,2 & 99,4 & 147,5 & 161,2 \\
\hline SSD 05 & 3,536 & 4,511 & 10,759 & 4,986 \\
\hline \multicolumn{5}{|c|}{ Bianca } \\
\hline Control & 90,8 & 97,2 & 157,5 & 168,1 \\
\hline FA 1 & 92,2 & 102,5 & 160,9 & 171,6 \\
\hline FA 2 & 98,0 & 108,1 & 168,3 & 181,5 \\
\hline SSD 05 & 4,998 & 4,531 & 5,522 & 6,650 \\
\hline
\end{tabular}

\section{Conclusion}

Thus, the proposed optimized technology for the leaf treatment application of the chelated micronutrient fertilizers has a pronounced positive effect on the phytosanitary vineyards condition and the grapes productivity. This occurs primarily due to the optimization of plant metabolism - maintaining a higher level of photosynthetic activity, leaves hydration during the season of critical growing and the proline accumulation in the leaves, which plays the role of a stress protector and ultimately affects the disease development and contributes to the complex indicators formation, such as productivity.

\section{References}

1. M.A. Altieri, C.I. Nicholls, A. Henao, M.A. Lana, Agronomy for Sustainable Development 35, 869-890 (2015) https://doi.org/10.1007/s13593-015-0285-2

2. N. Benkeblia, M. McHenry, J. Crisp, P. Roudier, Climate Change and Crop Production: Foundations for Agroecosystem Resilience (CRC Press, Taylor \& Francis Group 2018) https://doi.org/10.1201/9781315391861 
3. R.S. Jackson, Wine Science (Fifth Edition) Principles and Applications Food Science and Technology, 331-374 (2020) https://doi.org/10.1016/B978-0-12-816118$\underline{0.00005-2}$

4. A. C. Velásquez, C. D. M. Castroverde, S. Yang He, Current Biology, 28(10), 619634 (2018) https://doi.org/10.1016/j.cub.2018.03.054

5. E.G. Yurchenko, N.V. Savchuk, E.V. Porotikova, S.V. Vinogradova. Plant Disease 104(3), 991 (2019) https://doi.org/10.1094/PDIS-05-19-0938-PDN

6. M.V. Burovinskaya, E.G. Yurchenko, Fruit Growing and Viticulture of South Russia 58(4), 146-165 (2019) https://doi.org/10.30679/2219-5335-2019-4-58-146-165

7. V. Fernandez, T. Sotiropoulos, P.H. Brown, Foliar Fertilization: Scientific Principles and Field Pratices International Fertilizer (Industry Association (IFA) 2013) https://www.researchgate.net/publication/235609131

8. S. Davarpanaha, A. Tehranifara, Gh. Davarynejada, J. Abadíab, R. Khorasanic, Scientia Horticulturae 210, 57-64 (2016) https://doi.org/10.1016/j.scienta.2016.07.003

9. G. Brunetto, G. Wellington B. de Melo, M. Toselli, M. Quartieri, M. Tagliavini, Revista Brasileira de Fruticultura 37(4), (2015) https://doi.org/10.1590/0100-2945-103/15

10. A.-R. M.A. Mohamed, F.H. Abdel-Aziz, M.A. Mohamed, A. Gobara, Journal of Horticultural Research 21(2), 53-57 (2013) https://doi.org/10.2478/johr-2013-0021

11. C. M.H. Ferreira, C.A. Sousa, I. Sanchis-Pérez, S. López-Rayo, M. T. Barros, H. M.V.M. Soares, J. J. Lucena, Science of The Total Environment 647, 1586-1593 (2019) https://doi.org/10.1016/j.scitotenv.2018.08.069

12. J. Ma, M. Zhang, Zh. Liu, H. Chen, Y. C. Li, Y. Sun, Q. Ma, Ch. Zhao, Scientia Horticulturae 254, 106-115 (2019) https://doi.org/10.1016/j.scienta.2019.04.075

13. J.G. Martins, C.M.H. Ferreira, S.S. Dey, M.T. Barros, H. M. V. M. Soares Journal of the Iranian Chemical Society 14, 1079-1088 (2017) https://doi.org/10.1007/s13738-017$1057-5$

14. F. Yunta, I. Martín, J.J. Lucena, A. Gárate, Science and Plant Analysis 44(1-4), 794804 (2013) https://doi.org/10.1080/00103624.2013

15. M.K. Souri, M. Hatamian, Journal of Plant Nutrition 42(1), 67-78 (2019) https://doi.org/10.1080/01904167.2018.1549671

16. O. Hodek, T. Křžžek, P. Coufal, H. Ryšlavá, Analytical and Bioanalytical Chemistry, 409(9), 2383-2391 (2017) https://doi.org/10.1007/s00216-017-0184-2

17. N.P. Vlazan, R.O. Pop, P. Sfarloaga, I. Grozescu, A-E. Segneanu, Peptide and Amino Acids Separation and Identification from Natural Products (2012) https://doi.org/10.5772/51619

18. N.I. Nenko, N.N. Sergeeva, G.K. Kiseleva, Yu.I. Sergeev, E.K. Yablonskaya, Yu.F. Yakuba, Сельскохозяйственная биология, 53(3), 598-604 (2018) https://doi.org/10.15389/agrobiology.2018.3.598rus

19. K.G. Tikhonov, M.S. Khristin, V.V. Klimov, M.A. Sundireva, V.D. Kreslavski, R.A. Sidorov, V.D. Tsidendambayev, T.V. Savchenko, Russ J Plant Physiol 64, 73-82 (2017) https://doi.org/10.1134/S102144371606011X

20. E.G. Yurchenko, A.A. Luk'yanova, N.V. Savchuk, M.V. Burovinskaya, O.V. Orlov, S.V. Kononenko, Научные труды СКФНЦСВВ 23, 201-205 (2019) https://doi.org/10.30679/2587-9847-2019-23-201-205

21. Y. Wu, T. Qiu, Z. Shen, Y. Wu, D. Lu, J. He, Revista Brasileira de Fruticultura 40(5) (2018) https://doi.org/10.1590/0100-29452018037

22. A. Fernandes de Oliveira; F. Rais; I. Dettori; M. Azzena; G. Nieddu, South African Journal of Enology and Viticulture, 4(2) (2019) http://dx.doi.org/10.21548/40-2-3235

23. M. Svercel, D. Christen, G. Defago, Vitis 49(3), 137-144 (2010) https://doi.org/10.5073/vitis.2010.49.137-144 
24.Zh. Xu, Y. Jiang, G. Zhou, Frontiers in Plant Science 6, 701 (2015) https://doi.org/10.3389/fpls.2015.00701

25. M. Havaux, The Plant JournalSpecial Issue: Small Molecules: From Structural Diversity to Signalling and Regulatory Roles, 79(4), 597-606 (2014) https://doi.org/10.1111/tpj.12386

26. D. Latowski, P. Kuczyńska, K. Strzałka, Redox Report, Communications in Free Radical Research, 16(2), 78-90 (2011) https://doi.org/10.1179/174329211 $\underline{\mathrm{X} 13020951739938}$

27. Y. Luo, X. Zhao, H. Qu, X. Zuo, Sh. Wang, W. Huang, Y. Luo, M. Chen Acta Physiologiae Plantarum, 36, 381-388 (2014) https://doi.org/10.1007/s11738-013-1419-2

28. Z. Zsófi, S. Villangó, Z. Pálfi, E. Tóth, B. Bálo, Scientia Horticulturae, 172, 176-182 (2014) https://doi.org/10.1016/j.scienta.2014.04.008

29. I. Garrido, D. Uriarte, M. Hernández, J.L. Llerena, M. E. Valdés, F. Espinosa, International Journal of Molecular Science, 17(11), $1923 \quad$ (2016) https://doi.org/10.3390/ijms17111923

30. D.M. Kasote, S.S. Katyare, M.V. Hegde, H. Bae, Journal of Biological Sciences, 11(8), 982- 991 (2015) https://doi.org/10.7150/ijbs.12096

31. S. Hayat, Q. Hayat, M.N. Alyemeni, A.S. Wani, J. Pichtel, J. Ahmad, Plant Signaling and Behavior, 7 (11), 1456-1466 (2012) https://doi.org/10.4161/psb.21949

32. S. Mohammadrezakhani, J. Hajilou, F. Rezanejad, F. Zaare-Nahandi Journal of Plant Interactions, 14(1), 347-358 (2019) https://doi.org/10.1080/17429145.2019.1629033 